\title{
Pemanfaatan Bahan Alam Sebagai Terapi Komplementer Untuk Kesehatan Reproduksi Remaja
}

\author{
Budi Rahayu, ${ }^{1, *}$ Reni Merta Kusuma., ${ }^{2}$ Lily Yulaikah ${ }^{3}$ \\ 1,2,3,Kebidanani, Fkes Universitas Jenderal Achmad Yani, Yogyakarta, Indonesia \\ e-mail: ${ }^{1}$ budiayu_88@yahoo.co.id ${ }^{2}$ join.reni@gmail.com ${ }^{3}$ athasafaraz@gmail.com
}

\begin{abstract}
ABSTRAK
Indonesia adalah negara yang kaya raya. Potensi kekayaan alamnya sangat luar biasa, baik sumber daya alam hayati maupun non hayati. Bisa dibayangkan, kekayaan alamnya mulai dari kekayaan laut, darat, bumi dan kekayaan lainnya yang terkandung di dalam bumi Indonesia tercinta ini mungkin tidak bisa dihitung. Apabila dilihat secara geografis,dari sabang sampai merauke, terbentang tidak sedikit pulau yang ada di Indonesia. Sumber daya alam hayati Indonesia salah satunya sebagai penghasil bahan dasar obatobatan tradisional telah mengekspor ke berbagai manca negara dalam jumlah yang sangat besar. Tumbuhan obat merupakan salah satu keanekaragaman hayati nusantara yang tidak terpisahkan dari kehidupan masyarakat. Pemahaman masyarakat mengenai tumbuhan obat telah berkembang dan masyarakat mulai memahami bahwa sejauh ini penggunaan tumbuhan obat lebih aman dibandingkan dengan obat modern. Adapun beberapa senyawa aktif yang terkandung dalam tumbuhan obat yaitu atsiri, kurkumin, flavonoid, antosianin, tannin serta alkaloid yang baik untuk kesehatan manusia.

Masalah-masalah pada remaja diantaranya adaah seks bebas yang berakibat penularan penyakit menular seksual, kebersihan organ intim, Salah satu masalah pada kesehatan reproduksi remaja adalah dismenorhea, keputihan, Masalah kesehatan reproduksi remaja di Indonesia kurang mendapat perhatian yang cukup akibat pengetahuan mengenai kesehatan reproduksi seringkali masih dianggap tabu. Karena itu perlu adanya kesadaran dan peran serta dari berbagai instansi terkait untuk mampu memberikan pengetahuan mungkin mengenai pentingnya menjaga kesehatan reproduksi dan juga mensosialisasikan bahan alam untuk menjaga kesehatan organ reproduksi remaja . Hal ini dapat dilakukan secara nyata melalui upaya penyuluhan.

Berdasarkan hasil kegiatan program pengabdian masyarakat yang berupa Edukasi Pemanfaatan Bahan Alam Sebagai Terapi Komplementer Untuk Kesehatan Reproduksi Remaja terjadi peningkatan pengetahuan dari remaja, yang pertama peningkatan pengetahuan mengenai kesehatan reproduksi remaja dan yang kedua terjadi peningkatan pengetahuan remaja mengenai bahan alam apa saja yang bisa dimanfaatkan sebagai terapi komplementer untuk kesehatan reproduksi
\end{abstract}

KATA KUNCI : Bahan Alam; Kesehatan Reproduksi.

\section{ABSTRACT}

Indonesia is a rich country. The potential of its natural wealth is extraordinary, both biological and non-biological natural resources. Conceivably, its natural wealth ranging from the richness of the sea, land, earth and other wealth contained in this beloved Indonesian earth may not be counted. When viewed geographically, from sabang to merauke, there are not a few islands in Indonesia. Indonesia's biological natural resources, one of which as a producer of traditional medicines, have exported to various countries in huge quantities. Medicinal plants are one of the biodiversity of the archipelago that is inseparable from people's lives. 
Public understanding of medicinal plants has developed and people are beginning to understand that so far the use of medicinal plants is safer than modern medicine. While some active compounds contained in medicinal plants are essential, curcumin, flavonoids, anthocyanins, tannins and alkaloids that are good for human health.

Problems in adolescents include free sex resulting from transmission of sexually transmitted diseases, cleanliness of intimate organs, One of the problems in adolescent reproductive health is dismenorhea, whiteness, Adolescent reproductive health problems in Indonesia lack sufficient attention due to knowledge about reproductive health is often still considered taboo. Therefore, there needs to be awareness and participation from various relevant agencies to be able to provide as much knowledge as possible about the importance of maintaining reproductive health and also socializing natural materials to maintain the health of adolescent reproductive organs. This can be done in real time through counseling efforts.

Based on the results of community service program activities in the form of Education Utilization of Natural Materials as Complementary Therapy for Adolescent Reproductive Health there is an increase in knowledge from adolescents, the first increase in knowledge about adolescent reproductive health and the second there is an increase in adolescent knowledge about what natural materials can be utilized as complementary therapies for reproductive health

KEYWORDS : Material of natural; reproductive health.

\section{Pendahuluan}

Indonesia adalah negara yang kaya raya. Potensi kekayaan alamnya sangat luar biasa, baik sumber daya alam hayati maupun non hayati. Bisa dibayangkan, kekayaan alamnya mulai dari kekayaan laut, darat, bumi dan kekayaan lainnya yang terkandung di dalam bumi Indonesia tercinta ini mungkin tidak bisa dihitung. Apabila dilihat secara geografis,dari sabang sampai merauke, terbentang tidak sedikit pulau yang ada di Indonesia. Sumber daya alam hayati Indonesia salah satunya sebagai penghasil bahan dasar obat-obatan tradisional telah mengekspor ke berbagai manca negara dalam jumlah yang sangat besar. Tumbuhan obat merupakan salah satu keanekaragaman hayati nusantara yang tidak terpisahkan dari kehidupan masyarakat.

Pemahaman masyarakat mengenai tumbuhan obat telah berkembang dan masyarakat mulai memahami bahwa sejauh ini penggunaan tumbuhan obat lebih aman dibandingkan dengan obat modern. Adapun beberapa senyawa aktif yang terkandung dalam tumbuhan obat yaitu atsiri, kurkumin, flavonoid, antosianin, tannin serta alkaloid yang baik untuk kesehatan manusia. Tumbuhan obat disamping memiliki khasiat untuk kesehatan manusia juga memiliki kontribusi dalam biodiversitas hutan (Naemah, 2012). Pada umumnya masyarakat memanfaatkan khasiat dari tumbuhan obat salah satunya untuk mengobati berbagai penyakit yang diderita diantaranya penyakit pada organ reproduksi (Malo M., dkk, 2018).

Menurut World Health Organization (WHO), kesehatan reproduksi merupakan suatu keadaan fisik, mental dan sosial yang utuh, bukan hanya bebas dari penyakit atau kecacatan dalam segala aspek yang berhubungan dengan sistem reproduksi, fungsi serta prosesnya. Kesehatan reproduksi juga dapat didefinisikan sebagai suatu keadaan dimana manusia dapat menikmati kehidupan seksualnya serta mampu menjalankan fungsi dan proses reproduksinya secara sehat dan aman (Kemenkes RI., 2015). 
Masa remaja merupakan salah satu periode dari perkembangan manusia. Masa ini merupakan masa perubahan atau peralihan dari masa kanak-kanak ke masa dewasa yang meliputi perubahan biologi, perubahan psikologi, dan perubahan sosial. Masa remaja pada umumnya di mulai pada usia 10-13 tahun dan berakhir pada usia 18-22 tahun. Masa ini adalah masa yang penuh gejolak, masa yang penuh dengan berbagai pengenalan dan petualangan akan hal-hal baru sebagai bekal untuk mengisi kehidupan mereka kelak. Sayangnya, banyak remaja yang tidak sadar bahwa beberapa pengalaman yang tampaknya menyenangkan justru dapat menjerumuskan (Puji A, 2012).

Masalah-masalah pada remaja diantaranya adalah seks bebas yang berakibat penularan penyakit menular seksual, kebersihan organ intim, dismenorhea, keputihan. Masalah kesehatan reproduksi remaja di Indonesia kurang mendapat perhatian yang cukup akibat pengetahuan mengenai kesehatan reproduksi seringkali masih dianggap tabu. Studi pendahuluan dilakukan melalui survey kepada remaja-remaja mengenai kesehatan reproduksi berupa pengetahuan yang kurang tentang pemanfaatan bahan alam seperti batang sereh, jahe, daun sirih untuk mengatasi masalah kesehatan reproduksi mereka. selain itu pengetahuan mengenai kesehatan reproduksi mereka juga masih kurang. Karena itu perlu adanya kesadaran dan peran serta dari berbagai instansi terkait untuk mampu memberikan pengetahuan mungkin mengenai pentingnya menjaga kesehatan reproduksi dan juga mensosialisasikan bahan alam untuk menjaga kesehatan organ reproduksi remaja . Hal ini dapat dilakukan secara nyata melalui upaya penyuluhan.

\section{Metode}

a. Tahap Persiapan

Pada tahap persiapan ini kegiatan yang dilakukan adalah:

1) Menyusun proposal kegiatan

2) Melakukan sosialisasi kegiatan kepada sasaran

3) Mempersiapkan materi dan media yang akan digunakan

b. Tahap II : Pelaksanaan

Pada tahap ini kegiatan yang dilakukan adalah:

1) Bentuk kegiatan

Bentuk kegiatan ini adalah pemanfaatan bahan alam untuk kesehatan reproduksi dan pendidikan kesehatan mengenai kesehatan reproduksi pada remaja dan penyakit menular seksual.

2) Media dan Alat

Media yang digunakan untuk kegiatan ini adalah materi edukasi berupa power point dan video. Sedangkan alat yang dibutuhkan adalah alat bantu edukasi. Platform komunikasi menggunakan whatshapp class untuk kuliah dan penyampaian materi.

3) Peserta

Remaja putri dengan jumlah 21 peserta

4) Waktu pelaksanaan

Bulan Juli-Agustus 2020

5) Tahapan kegiatan dilakukan menjadi 2 sesi

Sesi 1 penyampaian materi tentang kesehatan reproduksi dan penyakit menular seksual

a) Pretest tentang kesehatan reproduksi dan penyakit menular seksual

b) Pemberian materi tentang kesehatan reproduksi dan penyakit menular seksual

c) Diskusi dan tanya jawab tentang kesehatan reproduksi dan penyakit menular seksual 
d) posttest tentang kesehatan reproduksi dan penyakit menular seksual Sesi 2 penyampaian materi tentang pemanfaatan bahan alam untuk kesehatan reproduksi

a) Pretest tentang pemanfaatan bahan alam untuk kesehatan reproduksi

b) Pemberian materi tentang pemanfaatan bahan alam untuk kesehatan reproduksi

c) Diskusi dan tanya jawab tentang pemanfaatan bahan alam untuk kesehatan reproduksi

d) Posttest tentang pemanfaatan bahan alam untuk kesehatan reproduksi

Sesi 3 Follow up dan evaluasi

c. Tahap III : Evaluasi dan Pelaporan

Pada tahap ini kegiatan yang dilakukan adalah:

1) Mengevaluasi hasil kegiatan.

Melihat masukan responden tentang evaluasi keseluruhan jalannya pengabdian kepada masyarakat

2) Menyusun laporan hasil kegiatan

\section{Hasil dan Pembahasan}

a. Edukasi Materi 1 Pendidikan Kesehatan Reproduksi Remaja dan Penyakit Menular Seksual

Data tingkat pengetahuan peserta sebelum dan setelah intervensi atau pemberian materi dapat dilihat pada Gambar 1. Hasil pretest rata-rata hasil rendah, namun setelah pemberian materi terdapat peningkatan tingkat pengetahuan peserta terkait edukasi kesehatan reproduksi dan penyakit menular seksual yang dapat dilihat dari nilai postest.

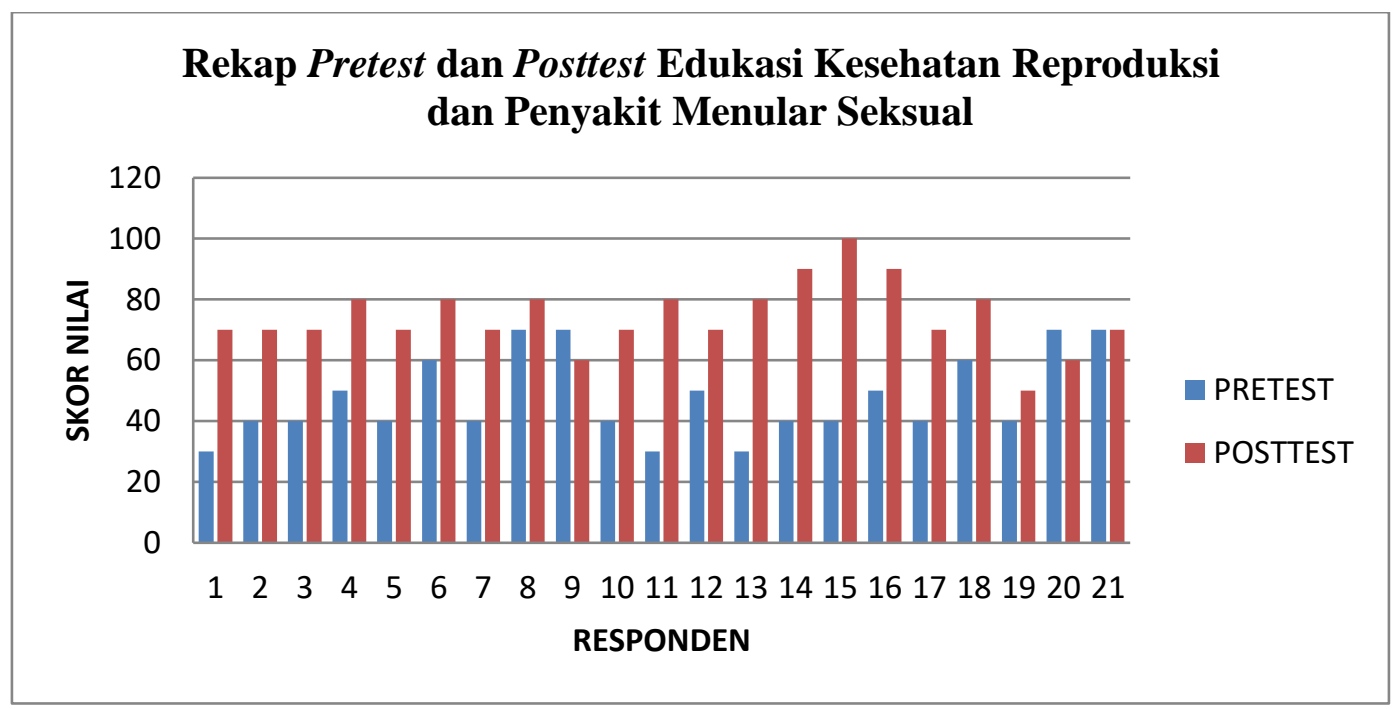

Gambar 1. Tingkat Pengetahuan Kesehatan Reproduksi Pretest dan Posttes.

Edukasi merupakan sebuah metode penyampaian informasi atau penyuluhan kepada seseorang atau sekelompok masyarakat dalam rangka peningkatan pengetahuan individu maupun kelompok. Selain diberikan dalam bentuk ceramah, demonstrasi, dan praktik, responden juga diberikan media leaflet dan video di dalam pelaksanaan kegiatan. Hasil pengabdian ini menunjukkan ada kenaikan pengetahuan tentang Kesehatan Reproduksi dan penyakit Menular Seksual. Data pada Gambar 2 menunjukkan bahwa kenaikan tingkat pengetahuan peserta edukasi 
$85.71 \%$ (18 orang). Pengetahuan yang mengalami penurunan $9.5 \%$ ( 2 orang), dan pengetahuan yang tetap adala $\mathrm{h} 4.7 \%$ (1 orang).

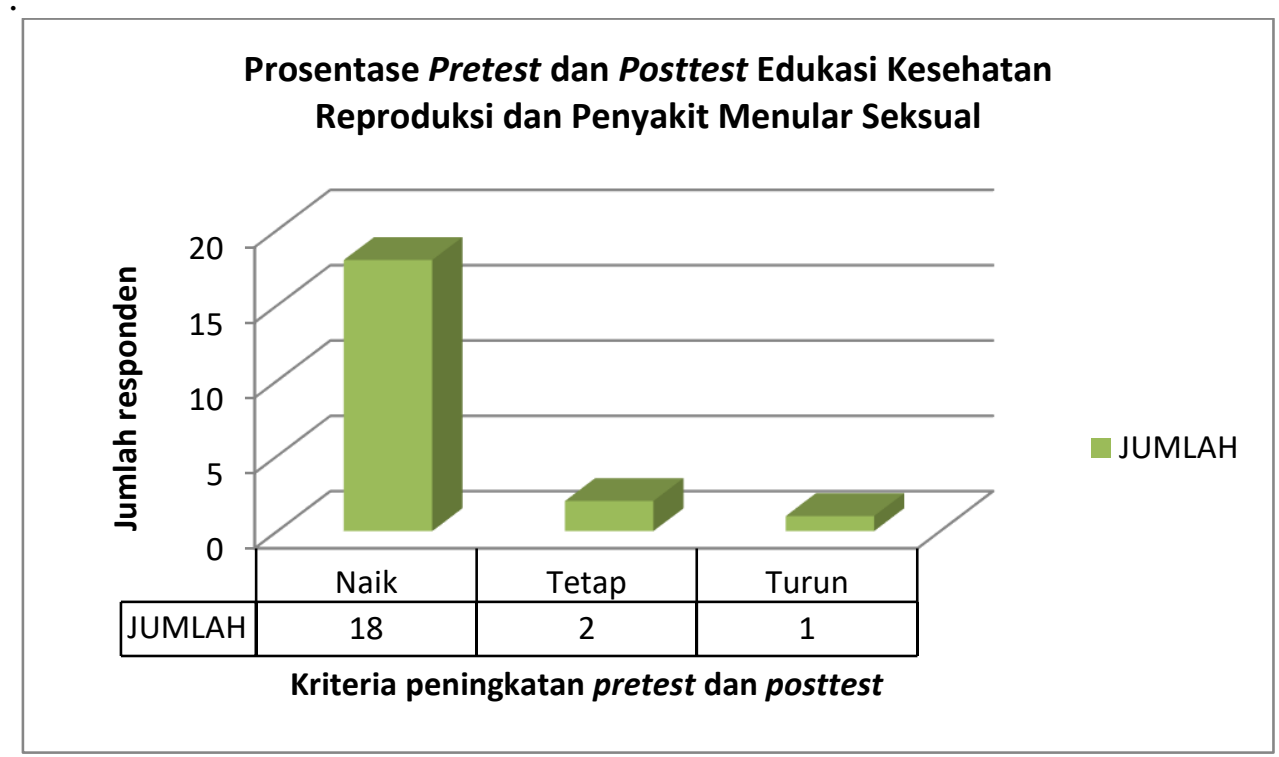

Gambar 2. Gambaran prosentase kenaikan tingkat pengetahuan tentang kesehatan reproduksi dan penyakit menular

\section{b. Materi 2 Pemanfaatan Bahan Alam sebagai Terapi Komplementer Kesehatan Reproduksi}

Data tingkat pengetahuan peserta sebelum dan setelah intervensi atau pemberian materi ke 2 dengan tema Pemanfaatan Bahan Alam sebagai Terapi Komplementer Kesehatan Reproduksi dapat dilihat pada Gambar 3. Hasil pretest rata-rata hasil rendah, namun setelah pemberian materi terdapat peningkatan tingkat pengetahuan peserta terkait edukasi dapat dilihat dari nilai postest yang banyak mengalami kenaikan.

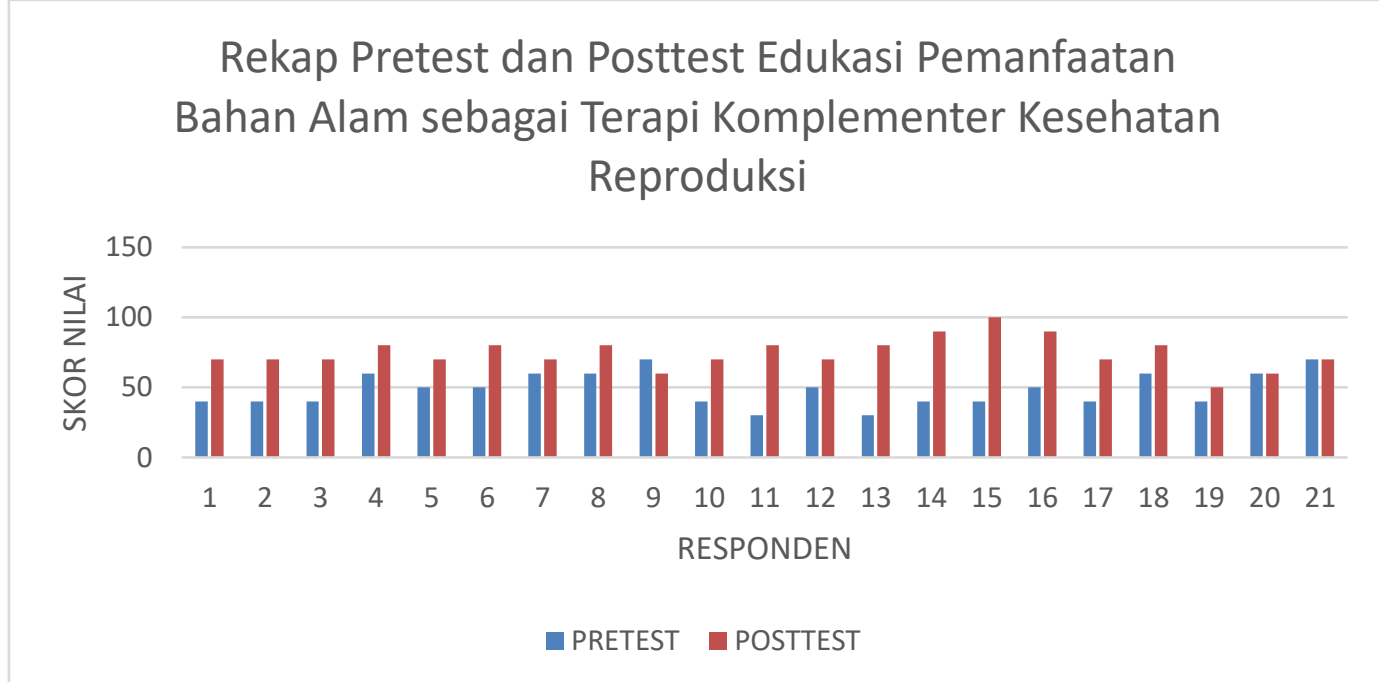

Gambar 3. Pemanfaatan Bahan Alam sebagai Terapi Komplementer Kesehatan Reproduksi Pretest dan Posttes 
Prosentase Pretest dan Posttest Pemanfaatan Bahan Alam sebagai Terapi Komplementer Kesehatan Reproduksi

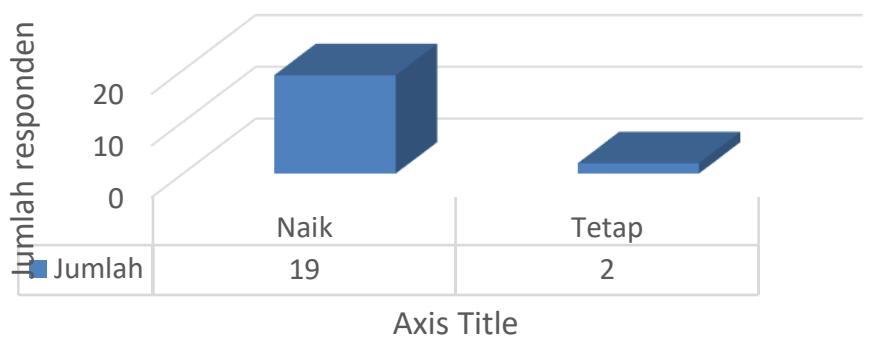

- Jumlah

Gambar 4. Gambaran prosentase kenaikan tingkat pengetahuan Pemanfaatan Bahan Alam sebagai Terapi Komplementer Kesehatan Reproduksi

Data pada Gambar 4 menunjukkan bahwa Diagram batang diatas menggambarkan bahwa kenaikan tingkat pengetahuan peserta edukasi $90.47 \%$ (19 orang). Pengetahuan yang tetap adalah 9.5\% (2 orang).

Kemudian evaluasi kegiatan dilakukan dengan memberikan kuisioner kepada peserta. Kuisioner yang diberikan berisi pertanyaan terkait materi dan media yang diberikan serta kinerja para pemateri dalam menyampaikan materi kepada peserta. Gambar 5. menunjukkan hasil sebagian besar peserta merasa puas dengan kegiatan ini.

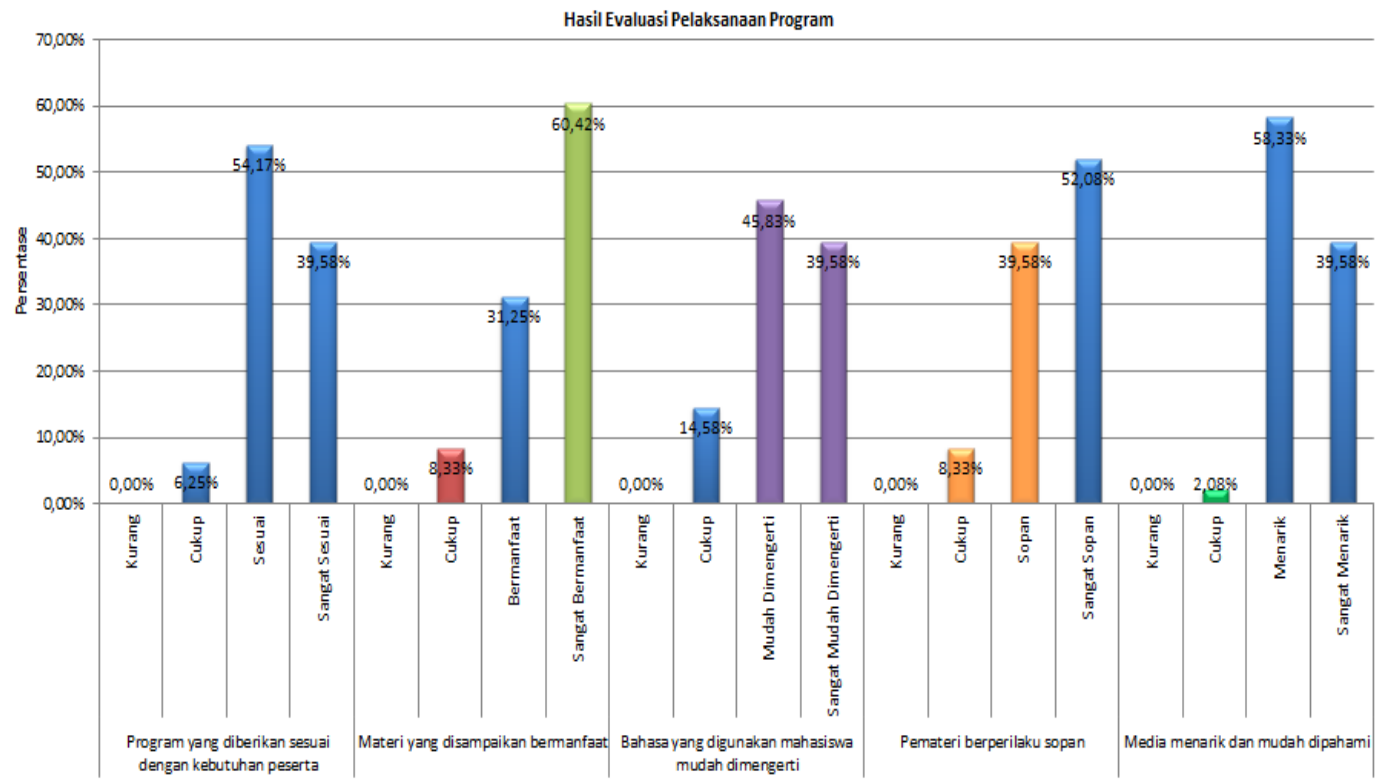

Gambar 5. Hasil evaluasi pelaksanaan program 


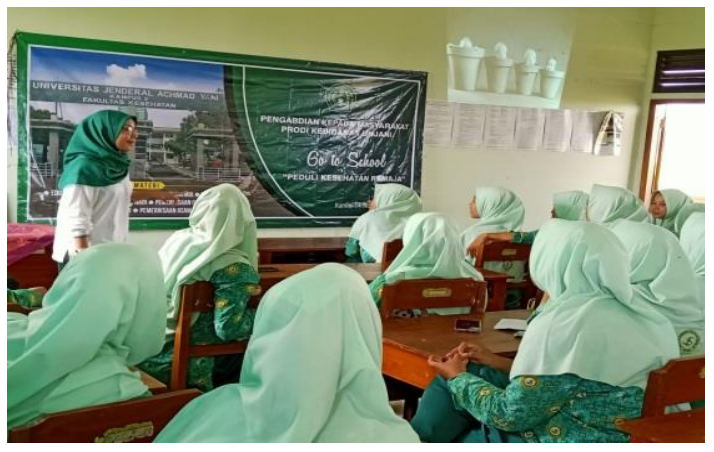

(a)

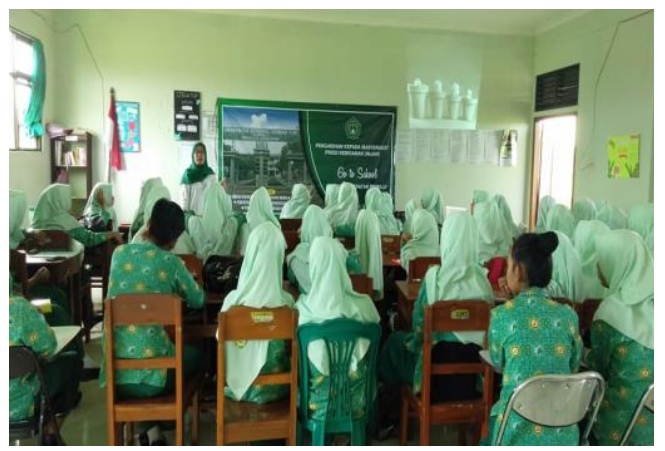

(b)

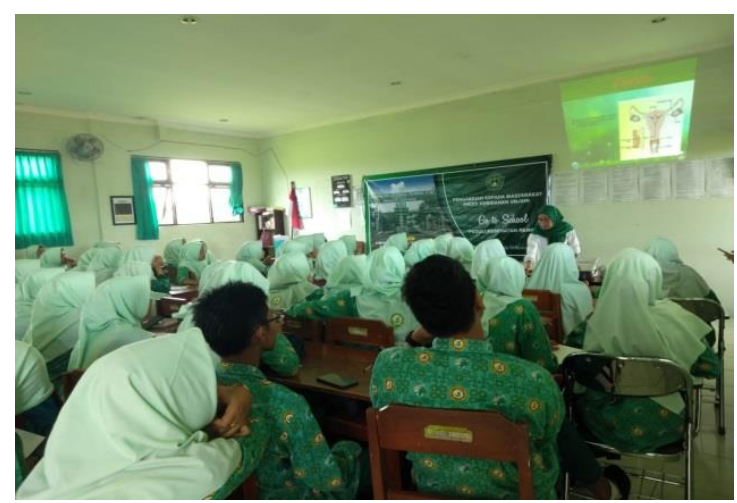

(C)

Gambar 6. Pretest (a), Penyampaian materi (b), Postest (c)

\section{Pembahasan}

\section{a. Hasil dan Pembahasan Materi 1 Pendidikan Kesehatan Reproduksi Remaja dan Penyakit Menular Seksual}

Menjaga kesehatan reproduksi adalah hal yang sangat penting, terutama pada remaja. Sebab, masa remaja adalah waktu terbaik untuk membangun kehiacaan baik menjaga kebersihan, yang b $\leadsto \quad$ jadi aset dalam jangka panjang. Rel (b) ;i bisa diartikan sebagai proses (c) pan manusia dalam menghasilkan kembali keturunan. Karena definisi yang terlalu umum tersebut, seringnya reproduksi hanya dianggap sebatas masalah seksual atau hubungan intim. Alhasih, banyak orang tua yang merasa tidak nyaman untuk membicarakan masalah tersebut pada remaja. Padahal, kesehatan reproduksi, terutama pada remaja merupakan kondisi sehat yang meliputi sistem, fungsi, dan proses reproduksi.

Kurangnya edukasi terhadap hal yang berkaitan dengan reproduksi nyatanya bisa memicu terjadinya hal-hal yang tak diinginkan. Salah satu hal yang sering terjadi karena kurangnya sosialiasi dan edukasi adalah penyakit seksual menular, kehamilan di usia muda, hingga aborsi yang berakibat pada hilangnya nyawa remaja. Nyatanya peran orangtua merupakan satu hal yang penting dalam edukasi seksual pada remaja. Apalagi saat ini masih belum banyak orang yang peduli terhadap risiko-risiko yang bisa menyerang remaja "salah pergaulan" tersebut. Mulai dari ancaman HIV/AIDS, angka kematian ibu yang meningkat karena melahirkan di usia muda, hingga kematian remaja perempuan karena nekat mengambil tindakan aborsi. Pada dasarnya, remaja perlu memiliki pengetahuan seputar kesehatan reproduksi. Tak hanya untuk menjaga kesehatan dan fungsi organ tersebut, informasi yang benar terhadap pembahasan ini juga bisa menghindari remaja melakukan hal-hal yang tidak diinginkan. Memiliki pengetahuan yang tepat terhadap proses reproduksi, serta cara menjaga kesehatannya, diharapkan mampu 
membuat remaja lebih bertanggung jawab. Terutama mengenai proses reproduksi, dan dapat berpikir ulang sebelum melakukan hal yang dapat merugikan.

Pengetahuan seputar masalah reproduksi tidak hanya wajib bagi remaja putri saja. Sebab, anak laki-laki juga harus mengetahui serta mengerti cara hidup dengan reproduksi yang sehat. Pergaulan yang salah juga pada akhirnya bisa memberi dampak merugikan pada remaja laki-laki pula. Pengetahuan yang diperlukan oleh para remaja diantaranya :

a) Pengenalan terhadap sistem, proses, serta fungsi alat reproduksi. Usahakanlah untuk menyampaikan informasi sesuai dengan usia dan kesiapan anak. Tapi sebaiknya hindari penggunaan istila-istilah tertentu yang malah bisa mengaburkan makna dan membuat anak tidak mengenal dengan pasti masalah reproduksi.

b) Risiko penyakit. Aspek ini juga sebaiknya sudah mulai dikenalkan dan disampaikan pada remaja yang sudah beranjak dewasa. Dengan mengetahui risiko yang mungkin terjadi, remaja tentu akan lebih berhatihati dan lebih menjaga kesehatan reproduksi.

Kekerasan seksual dan cara meghindarinya. Remaja perlu dikenalkan dengan hak-hak reproduksi yang ia miliki. Selain itu, diperlukan juga pengetahuan tentang kekerasana seksual yang mungkin terjadi, apa saja jenisnya, dan bagaimana cara mencegahnya terjadi.

\section{b. Hasil dan Pembahasan Materi 2 Pemanfaatan Bahan Alam sebagai Terapi Komplementer Kesehatan Reproduksi}

Indonesia merupakan negara tropis dengan potensi tanaman yang secara turun temurun digunakan sebagai obat tradisional. Jamu, yang merupakan obat tradisional Indonesia, telah menjadi budaya masyarakat Indonesia sejak berabad silam sebagai bagian dari upaya menjaga kesehatan, menambah kebugaran, dan merawat kecantikan. Industri, usaha dan sub sektor jamu dan obat tradisional serta kosmetik di Indonesia semakin berkembang sejak tahun 2008 melalui kegiatan "Jamu Brand Indonesia" yang dicanangkan oleh Presiden RI 2009-2014 Susilo Bambang Yudoyono pada Gelar Kebangkitan Jamu Indonesia. Jamu mempunyai peluang besar dengan adanya kekayaan keanekaragaman hayati. Indonesia dikenal secara luas sebagai mega center keanekaragaman hayati (biodiversity) terbesar ke-2 di dunia setelah Brazil, terdiri dari tumbuhan tropis dan biota laut. Di wilayah Indonesia terdapat sekitar 30.000 jenis tumbuhan dan 7.000, di antaranya ditengarai memiliki khasiat sebagai obat. Sebanyak 2500 jenis di antaranya merupakan tanaman obat. Dengan potensi yang dimiliki tersebut, Indonesia mempunyai prospek untuk pengembangan jamu bagi kepentingan kesehatan, produk industri, maupun pariwisata, dengan sasaran pasar dalam negeri maupun internasional. Industri jamu telah masuk ke dalam 10 produk prospektif yang perlu dikembangkan karena memiliki potensi pasar menjanjikan di pasar lokal maupun global. Permintaan jamu mengalami peningkatan dengan pertumbuhan pangsa pasar yang lebih baik daripada tingkat pertumbuhan industri farmasi. Terdapatnya tren back to nature mengakibatkan masyarakat semakin menyadari pentingnya penggunaan bahan alami bagi kesehatan. Masyarakat semakin memahami keunggulan penggunaan obat tradisional, antara lain: harga yang lebih murah, kemudahan dalam memperoleh produk, dan mempunyai efek samping yang minima

Dengan diberikan edukasi dan diulas kembali tentang pemanfaatan bahan alam seperti jahe, kunyit, daun sirih, jenis rimpang yang bisa dimanfaatkan untuk kesehatan reproduksi remaja. Remaja menjadi mengerti manfaat jamu untuk kesehatan reproduksi yang bisa digunakan untuk mengatasi diminore, keputihan dan juga melancarkan haid. 


\section{Kesimpulan}

Berdasarkan hasil kegiatan program pengabdian masyarakat yang berupa Edukasi Pemanfaatan Bahan Alam Sebagai Terapi Komplementer Untuk Kesehatan Reproduksi Remaja terjadi peningkatan pengetahuan dari remaja, yang pertama peningkatan pengetahuan mengenai kesehatan reproduksi remaja dan yang kedua terjadi peningkatan pengetahuan remaja mengenai bahan alam apa saja yang bisa dimanfaatkan sebagai terapi komplementer untuk kesehatan reproduksi.

\section{Ucapan terima kasih}

Dalam kesempatan ini ucapan terima kasih kami tujukan kepada Kuswanto Hardjo, dr., M.Kes. selaku Dekan Fakultas Kesehatan Universitas Jenderal Achmad Yani Yogyakarta, Deby Zulkarnain, R.S, S.Kep., Ns., MMR. selaku Ketua PPPM Fakultas Kesehatan Universitas Jenderal Achmad Yani Yogyakarta, Reni Merta Kusuma, S.ST.,M.Keb. selaku Ketua Program Studi Kebidanan (S-1) Universitas Jenderal Achmad Yani Yogyakarta, seluruh responden pengabdian kepada masyarakat dan mahasiswi yang telah membantu proses pelaksanaan pengabdian kepada masyarakat.

\section{Daftar pustaka}

[1] S. Pujiastuti, Yoga untuk Kehamilan Sehat, Bahagia, Penuh Makna. 2012.

[2] Kementrian Kesehatan RI., Pedoman Nasional Penanganan Penyakit Menular Seksual. Jakarta, 2011.

[3] Kementrian Kesehatan RI., Kesehatan Reproduksi dan seksual Bagi Calon Pengantin. Jakarta: Kemenkes RI, 2015.

[4] Kementerian Kesehatan RI., Buku Saku Remaja pada Situasi Krisis Kesehatan. Jakarta: Kemenkes RI., 2017.

[5] M. Malo, "Tumbuhan obat untuk kesehatan reproduksi di kecamatan Kuatnana kabupaten tts.," Media Farm. Indones., vol. 12, no. 2, 2017.

[6] D. Naemah, "Inventarisasi Tanaman bagi Masyarakat Dayak di Kec matan Hantakan Kabupaten Hulu Sungai Tengah. Banjarbaru," J. mandiri Tumbuh. Obat, 2012.

[7] Indonesia, PP No. 61 Tahun 2014 Tentang Kesehatan Reproduksi. 2014.

[8] S. Romauli, Kesehatan Reproduksi. Yogyakarta: Nuha Medika, 2012.

[9] R. Wahyudi, Modul Kesehatan Reproduksi Remaja. MCR-PKBI, 2013.

[10] Indonesia, UU Kesehatan No. 36 Tahun 2009. 2009. 